\title{
A história de Eli. Um professor de Física no início de carreira
}

\author{
Nelson Rui R. Bejarano ${ }^{1}$ e Anna Maria P. de Carvalho ${ }^{2}$ \\ ${ }^{1}$ Departamento de Química Geral e Inorgânica, Universidade Federal da Bahia \\ ${ }^{2}$ Faculdade de Educação, Universidade de São Paulo \\ Recebido em 14/12/03; Revisto em 01/04/04; Aceito em 08/04/04
}

\begin{abstract}
O presente estudo é uma pesquisa qualitativa do tipo estudo de caso que acompanhou a trajetória de um professor de física que estava começando a dar aulas no ano de 1998, mas ainda concluindo seu curso de formação inicial de professores de física. Ao acompanhar esse professor estudamos os principais conflitos e preocupações educacionais que surgiam naquele período de sua vida, bem como as estratégias que usava para enfrentar essas situações.

Palavras-chave: ensino de Ciências, conflitos, crenças, preocupações, formação inicial de professores.
\end{abstract}

The present study is a qualitative research of one case study kind that followed the route of one teacher who was starting his teaching career in 1998, but was still finishing his course on initial formation of Physics teachers. To follow this teacher we have utilized the new teachers professional development concept. This concept involves detection, evolution and conflict solving, and professionals concerns inherent to teachers development.

Keywords: Science teaching, concerns, conflicts, beliefs, preservice teachers.

\section{Introdução}

O objetivo original dessa pesquisa é o de identificar as crenças educacionais trazidas por 3 professores de física e os conflitos que emergiram em decorrência dessas crenças, quando estavam no programa de formação inicial em uma universidade pública brasileira, no ano de 1998. Esse estudo se constituiu em nossa tese de doutoramento concluída em 2001. No entanto, para os objetivos desse artigo incluiremos a análise de apenas um desses três sujeitos que originalmente foram estudados; o chamaremos apenas de Eli. Eli estava se iniciando na profissão como professor de física no ensino médio, embora naquele ano letivo ainda fosse aluno de licenciatura do curso de Física dessa mesma universidade, tendo sido acompanhado por todo o ano letivo de 1998 e durante o primeiro semestre do ano letivo de 1999. Investigamos esse professor novato na disciplina então denominada Prática de Ensino de Física, que é oferecida em dois semestres consecutivos, normalmente já no final do programa. Essa disciplina envolve uma carga horária semanal de 5 horas de aulas na universidade, sendo que, além disso, nesses dois semestres, os futuros professores desenvolvem o que se chama de Estágio Supervisionado que significa um número determinado de atividades junto às escolas de nível médio dentro do ensino de física. O relato dessa pesquisa se refere então a esses contextos escolares em que Eli se iniciou na profissão de professor de física. Ao se encontrar no final de seu curso de formação inicial e além disso já estar na condição de professor efetivo, em seu primeiro ano de profissão, nosso sujeito de pesquisa teve a oportunidade de expor em vários momentos da investigação suas crenças, preocupações e conflitos educacionais. A relevância do levantamento de crenças educacionais do professor em início de carreira bem como o levantamento dos principais conflitos e preocupações educacionais experimentados por ele nesse interregno em que é aluno de final do curso de licenciatura, mas já se iniciando de forma mais estável na profissão de professor de física, são apontados pela literatura de formação inicial como um momento crucial do início do desenvolvimento profissional desse professor. Dos autores que nos ajudaram a entender essas trajetórias destacamos principalmente Fuller [6] que propõe um modelo de desenvolvimento em fases do professor, na medida em que resolve classes de preocupações educacionais. Fuller propôs três fases de preocupações: a fase do pré-ensino, caracterizada pela escassa ou inexistente experiência de ensino do sujeito, que o leva a basicamente não ter preocupações com o ensino; a fase de preocupações denominada 'primeiros contatos com o ensino', em que a preocupação é mais auto-centrada no professor novato, onde ele tenta avaliar os limites de sua aceitação dentro do novo ambiente. Também é característica dessa fase a obcessão pelo controle da sala de aula, o medo de não dominar o conteúdo e dificuldades com os processos de avaliação; finalmente, uma fase de preocupações posteriores, ou na linguagem de Fuller, a fase de late concerns, em que o campo de preocupações se descentra, dirigindo-se mais aos próprios alunos, seus ganhos

${ }^{1}$ Enviar correspondência para Nelson Rui R. Bejarano. E-mail: bejarano@ufba.br.

Copyright by the Sociedade Brasileira de Física. Printed in Brazil. 
e seus processos de aprendizagem [6]. Já Beach \& Pearson [2] estudaram as principais tensões e conflitos que surgem no início da profissionalização do professor além de destacar formas ou estratégias utilizadas no enfrentamento desses problemas. Detectouse quatro tipos principais de conflitos durante o pré-serviço que é equivalente à nossa licenciatura plena. Participantes desse estudo se referiram a conflitos pessoais em suas relações com os estudantes, com professores cooperadores, colegas professores, administradores. A origem desse conflito surgia porque, em alguns casos, os participantes simplesmente não conseguiam progresso com os estudantes ou não concordavam com as crenças educacionais dessas pessoas, mas eles não sabiam como reconciliar essas diferenças. Houve também detecção de conflitos relacionados a questões de currículo e instrução. Esse conflito se relacionava principalmente com o fato de, a despeito de prepararem suas aulas com atenção, os estudantes não responderem positivamente à instrução como o professor previa. Detectou-se também conflito entre o currículo da escola e o currículo do professor. Professores em curso de pré-serviço podem desenvolver conflito relacionado ao seu autoconceito ou papel como professor. Incluem-se aqui problemas como o papel de ambigüidade durante a transição de estudante para professor. Nesse caso o estudo relata a luta do professor novato, entre ser um amigo para os estudantes versus ser uma figura de autoridade. Participantes desse estudo exprimiram, além disso, também conflitos relacionados à expectativa com o programa da universidade, ou então com as complexidades e políticas do sistema escolar e pressões para se socializar com a cultura das escolas e do ensino. Esse conflito, foi denominado como conflito institucional. Instalados, os conflitos dos professores inexperientes são manejados de maneira bem pessoal. Nesse mesmo estudo, os autores sugeriram uma categorização em três níveis de hierarquia crescente, tipificando as estratégias utilizadas pelos professores estudantes de seu estudo para enfrentarem os conflitos emergentes. Estratégias de nível I: caracterizam-se pela negação, recusa e afastamento dos conflitos, com evidências de declínio com o passar do tempo. Obviamente, essa estratégia não leva a questionamento de crenças sobre o ensino e aprendizagem. Participantes descrevem o conflito mascarando-o ou racionalizando-o; enfim, dando uma justificativa para o conflito, mas não discutindo também nenhuma estratégia para lidar com ele. Professores podem também usar estratégias de nível II: gerando somente recursos de solução de curto prazo. Nesse caso, freqüentemente as soluções formuladas procuram mudar fatores externos - disciplinando desrespeito dos estudantes ou fazendo revisão no planejamento de uma aula problemática. Todavia, estas estratégias de nível II levam a pouca interrogação de suas teorias pessoais de ensino ou sistema de crenças. Mesmo que estas estratégias de curto prazo possam produzir temporariamente alívio, elas freqüentemente não se endereçam às crenças e atitudes que estão subjacentes ao conflito.Com pouca evidência de estratégias de nível III até o meio do programa, há um aumento considerável, a partir daí, até o primeiro ano de ensino. Eles ganham mais consciência da complexidade do ensino e ficam mais abertos a interrogar suas próprias percepções e teorias de ensino, originando um alto sentimento de necessidades de mudança. Começam também a reconhecer que sua visão de escola simplista não é adequada para explicar a complexidade de suas experiências. Estratégias de nível III: envolvem a consideração e/ou implementação de mudança de longo prazo nas crenças. Outros autores em que nos apoiamos também se caracterizam por dar um sustentamento empírico aos estudos de Fuller [6] além de estarem preocupados exatamente com essa fase de transição que nos referimos onde há ambigüidades entre ser um aluno de licenciatura mas já estar trabalhando de forma estável como professor e não apenas como estagiário. [8-11,14] entre outros. Já o conceito de crenças educacionais do professor, indicamos um artigo de revisão sobre o tema [12], que consideramos importante porque indica o estado da arte das pesquisas educacionais sobre crenças (beliefs) além de proporcionar uma discussão que nos foi bastante frutífera para o estabelecimento das relações causais entre crenças educacionais do professor novato e o estabelecimento de conflitos e preocupações educacionais. No final do primeiro semestre letivo de 1998, nosso professor desse estudo foi submetido a uma entrevista aberta, quando pode expor de maneira detalhada as principais preocupações emergidas nos seus primeiros meses como professor. Ao mesmo tempo foram observadas as estratégias de enfrentamento que Eli estava utilizando para resolver essas preocupações. Sua percepção de formas de ajuda vinda das disciplinas do programa de formação inicial também foi objeto de discussão nessas entrevistas, que tiveram ainda como fonte privilegiada de dados um 'diário de campo do professor', que fazia parte das atividades solicitadas pela disciplina de formação. Nesse diário havia reflexões do licenciando acerca de várias atividades de sua prática de ensino, solicitadas pela disciplina. Uma nova entrevista foi realizada em maio do ano letivo de 1999. Novamente, o foco dessa entrevista aberta se ateve aos objetivos definidos na primeira entrevista. O detalhe importante é que fazia um ano de nossa primeira entrevista, de maneira que buscamos refazer a trajetória de Eli em termos de seu desenvolvimento profissional nesse período. O diário de campo do professor construído no segundo semestre também foi utilizado como fonte de dados, a exemplo do que fizemos no primeiro semestre. Como fonte final de extração de dados filmamos todas as aulas de Prática de Ensino de Física II ocorridas na universidade no segundo semestre de 1998. A transcrição e análise desses dados foram fundamentais para compormos nossa análise utilizando fontes de dados diversas. A discussão que se segue foi uma tentativa de especular sobre o impacto que se origina quando um professor de ciências se inicia na carreira, mesmo ainda estando dentro da universidade e cursando disciplinas da formação inicial do final do programa. Nossa análise não pretende ser definitiva porém, acreditamos que desse estudo de caráter qualitativo possam surgir novas questões para a pesquisa sobre formação inicial do professor de ciências.

\section{As questões de pesquisa}

Partindo do pressuposto de que a profissão de professor é eminentemente conflituosa e complexa e que os primeiros momentos iniciais dos professores novatos na profissão potencializam esses conflitos, a despeito dos esforços dos cursos de licenciatura, buscaremos estudar quais são os principais conflitos e preocupações que surgem quando o licenciando inicia experiências sistemáticas como professor novato dentro do ensino de física do nível médio. Procuramos visualizar quais são essas preocupações e conflitos profissionais, a 
origem e sua natureza e, eventualmente, se ao longo do desenvolvimento das disciplinas de formação inicial e pelo período posterior que o acompanhamos, essas preocupações e conflitos detectados evoluem ou não para uma solução. Investigaremos também quais são as percepções que nosso sujeito, na condição de professor novato, licenciando do curso de física, teve de possíveis apoios recebidos junto às disciplinas de formação inicial, ou de qualquer experiência relevante ocorrida durante o curso de licenciatura em física. Se ele detectou apoios, no sentido de ajudá-lo a resolver seus conflitos e problemas que porventura surgiram quando iniciou a ministrar aulas de física.

\section{A história de Eli}

Eli estava começando a ministrar aulas de física no ensino médio apenas a partir daquele ano em que este estudo se iniciou: o ano de 1998. Morando em uma cidade da chamada Grande São Paulo, Eli estava terminando o programa de formação inicial de professores de física, vindo do período noturno da mesma instituição. Sua trajetória dentro do programa não foi das mais suaves. Eli estava completando o curso de licenciatura em física no décimo ano após o seu ingresso. Importante que não o julguemos a priori apenas por esse fato; é sabido que, no curso de licenciatura em física do período noturno, a média de tempo para cumprir todos os créditos é muito maior do que no mesmo curso do período diurno. Contribui para isso obviamente o fato dos licenciandos do período noturno serem trabalhadores, o que em parte justifica uma formação mais demorada. Eli iniciou-se na profissão, ministrando aulas de física em duas escolas da região onde morava, uma escola pública do período noturno e uma outra escola particular do período diurno. Dois contextos distintos que foram sua porta de entrada para a profissão. Foi também nessas duas escolas que Eli desenvolveu seu Estágio Supervisionado dentro das disciplinas de Prática de Ensino de Física I e II. Eli também viveu intensamente as preocupações e conflitos próprios da profissão, que afligem especialmente o professor novato. Optamos por deixar o próprio Eli, 37 anos em 1998, nos contar um pouco de sua trajetória familiar, tentando superar uma conjuntura difícil e marcada por dificuldades de várias naturezas. Em seguida, ele nos relata também como se deu sua aproximação com o ensino de física, na qual o encontramos já quase terminando sua licenciatura em física, no ano de 1998.

Meus pais nasceram no interior, na zona rural, próximo à divisa entre Minas Gerais e Espírito Santo. A Educação formal no caso deles foi inexistente. Na verdade, não sei dizer como eles aprenderam a ler e a escrever, já que não freqüentaram os bancos escolares. No tempo deles, estudar era coisa de desocupado, de vagabundo. Eles perceberam que estuar era coisa de quem podia e, que quem podia, sempre estudava e se dava bem na vida. Provavelmente por isto meus pais sempre incentivaram os estudos e, no iníco, minha mãe cuidou da alfabetização com as velhas cartilhas, o que de certo modo nos garantiu um diferencial nos primeiros anos escolares. Com isso, ter sucesso escolar era uma obrigação para os mais novos. Os mais velhos acabaram servindo de padrão, sem reprovações e sempre colocados entre os melhores, o que enchia mamãe de orgulho e papai de satisfação. $O$ valor que eles sempre deram à Educação talvez tenha vindo da impossibilidade de estudar por que passaram. Assim, investiram nos filhos, para que estes realizassem seus sonhos. O resultado foi uma família que sempre foi aprovada e hoje, com exceção de um entre sete, todos cursaram pelo menos uma Faculdade, tendo antes participado de um curso técnico, o que serviu para garantir emprego e renda. Como carreira, de modo geral, os homens escolheram atividades industriais e as moças atividade de escritório, uma visão bem metalúrgica da vida. Estas escolhas sem dúvida alguma nasceram do universo de sucesso que tínhamos diante dos olhos, e que nos serviam de horizonte, uma vez que meus pais, apesar de toda boa vontade, não tinham uma cultura capaz de nos encaminhar para outras carreiras. Eles não sabiam como fazer isso. Só sabiam que era importante estudar. Nestas escolhas ficamos assim: Eli, técnico em eletrônica, tecnólogo em eletrônica, licenciado em Física (...). Ainda não acabamos, e pode-se dizer que, do item educação formal, os coroas não têm do que reclamar dos filhos. Não é nada mau para um casal de pouca instrução, mas de um valor impressionante. Como cheguei ao magistério: como já disse, eu sempre estive entre os melhores, nas escolas onde estudei é claro, e não eram escolas de primeira linha. Como carreira, eu escolhi no início alguma coisa que pudesse garantir uma melhora financeira, e é bom lembrar que isso deu certo, já que consegui um padrão que muitos jamais terão: tenho duas casas, terreno e não devo nada. Ensinar era uma atividade pensada para a época da aposentadoria, quando eu deixasse o trabalho na indústria, até porque professor ganha mal mesmo (...) [no entanto...] eu, que sempre fui bom aluno, sempre fiz uma ótima imagem do professor e, mesmo sabendo que o salário não era dos melhores, passei a planejar o meu ingresso na área, o que se deu em 1998. Hoje, estou trabalhando em duas escolas e o salário ainda é inferior ao salário industrial, porém está melhorando depressa e creio que em breve terei unido o útil ao agradável.

E assim iniciamos uma escalada para conhecermos um pouco mais da vida de Eli, destacando para nós alguns aspectos essenciais do ponto de vista de sua opção pela Educação. Seus dados biográficos revelam dificuldades familiares, família de origem humilde. Os pais não tiveram instrução formal. Há uma superação entre os filhos, com o apoio dos pais e tudo mais o que nos relatou. Porém, o que nos chamou primeiramente a atenção foi a formação de Eli. Ele já entrou no programa aos 27 anos aproximadamente, vindo de uma formação da área técnica. Técnico em eletrônica no nível médio e tecnólogo também em eletrônica no nível superior. Em sua pequena biografia, ele fala que sua família tinha "uma visão bem metalúrgica da vida”. É bom explicar também que sua família, quando saiu do interior, se instalou em uma região da Grande São Paulo, onde existem as maiores indústrias metalúrgicas do Brasil. Mas, ao adotar essa visão metalúrgica da vida, Eli investiu grande parte de sua formação na direção de uma área técnica. Trabalhou como projetor de máquinas entre 1987 e 1992 e como corretor imobiliário entre 1993 e 1998. Entre 1986 e 1989, concluiu o curso de tecnologia em eletrônica do nível superior. Ele entrou na licenciatura em física em 1991 (no período noturno e só em 1998 se transferiu para o período diurno). Ficou um tempo ainda na área técnica e caminhou pela área do comércio. Em seguida, foi para o ramo imobiliário. Enfim, mesmo dentro da licenciatura, suas apostas profissionais se dirigiam para outras áreas. Alegava que a questão financeira era um impeditivo para sua ida para a 
Educação. E, só a partir do final de sua longa trajetória na licenciatura, resolveu de fato ir para a sala de aula, sete anos após seu ingresso. Era como se ele estivesse no programa e como ele mesmo dissesse, de forma irônica, que só pensava em dar aulas "para a época da aposentadoria”. Sua profecia não se realizou e em 1998, aos 37 anos, Eli começou a dar aulas de física para o Ensino Médio. Preocupações e conflitos profissionais dos professores novatos não estão ligados à sua idade cronológica e sim ao desenvolvimento contado a partir da conformação de suas crenças sobre o que é o ensino e a aprendizagem em ciências, qual o papel da escola - estabelecido em períodos de sua vida escolar anterior à Universidade, seu ingresso no programa de pré-serviço, seus primeiros contatos sistemáticos com o ensino e, finalmente, sua opção pelo ingresso na profissão. Desta forma, Eli viveu intensamente preocupações e conflitos profissionais, desde o primeiro dia em que começou a dar aulas de física. Eli é casado e não tinha filhos.

\section{Primeiro semestre de Eli como pro- fessor}

O contexto das escolas em que começou a trabalhar era o seguinte: a escola pública localizada no centro de uma cidade daquela região onde morava e a escola particular na periferia de uma outra cidade da mesma região. Na escola pública, as aulas de Eli eram no período noturno, para os três anos do Ensino Médio, e sua jornada de trabalho era de segunda a sexta-feira. Na escola particular, que era de orientação católica, trabalhava no período da manhã, também com os três anos do Ensino Médio, apenas dois dias por semana.

Em março de 1998, no primeiro semestre da disciplina de Prática de Ensino de Física I, começamos de fato a nos aproximar das crenças de Eli em relação ao ensino de física no nível médio. Através de uma atividade que a pesquisa transformou em instrumento, solicitada pela professora da Universidade, que denominamos 'Síntese I', os licenciandos tinham que individualmente resgatar um pouco de sua história como alunos de física do ensino médio, falando também de seus professores. Mas basicamente ponderavam criticamente sobre a validade do ensino tradicional de física para o Ensino Médio, se necessário resgatando alguma contribuição que a licenciatura pudesse ter dado para iluminar a questão.

Eli foi um daqueles de um grande grupo de licenciandos que se posicionou, naquele período, a favor do ensino tradicional. Seu depoimento foi extremamente curto. Para se ter uma idéia, ao responder sobre a validade do ensino tradicional, disse simplesmente "Sim, eu acho válido". Seu argumento para essa posição era de que "o ensino tradicional requer poucos materiais e ambientes comuns e ainda dá grande ênfase às cobranças”.

Disse também naquela ocasião que suas aulas no ensino médio tinham sido expositivas, sem nenhum comentário adicional.

Sobre seu melhor professor de física, falou um pouco mais e assim o definiu:

Com o meu melhor professor, eu só 'aprendi' e aumentei o gosto pela física. De física mesmo, aprendi muito pouco, mas ele era extremamente comunicativo, tinha grande mobilidade na sala e conseguia dizer o que se quer ouvir. Conseguia fazê-lo sentir-se capaz.

De seu pior professor, também guardava uma lembrança, no caso não muito favorável.

Meu pior professor era extremamente sisudo, metódico e antipático. Conseguia levar à classe um medo incrível, dele e também da matéria.

Sobre sua auto-avaliação como aluno de física do ensino médio, disse que teve sucessivos sucessos que o fizeram ser um aluno dedicado.

Talvez a construção do papel de professor que Eli estava começando a compor de maneira mais efetiva, tivesse elementos desse período, talvez desses seus professores, do pior ou do melhor. Embora nada indicasse naquela época que ele fosse para a área de ensino de física, o aprendizado pela observação, que ocorre nesses períodos em que são aprendizes do ensino médio, parece ser algo sobre o qual não há discordância [8],[10],[12].

Das duas escolas que Eli começou a trabalhar, escolheu para desenvolver seu estágio a escola pública de período noturno, junto a uma classe de segundo ano do ensino médio.

O planejamento de Eli, apresentado para efeito de seu Estágio Supervisionado, se constituía em tópicos de conteúdos de física tradicionalmente trabalhados naquele nível de ensino: Força (Leis de Newton), Atrito, Trabalho de uma Força. Dava a impressão que os próprios tópicos dos conteúdos foram retirados integralmente do livro didático que resolveu adotar [13].

Não se observava em seu planejamento nenhuma alusão às concepções prévias dos estudantes, tampouco ao desenvolvimento de atividades experimentais. Em concordância com Mellado [10], professores de ciências novatos tendem a fazer seus planejamentos baseados principalmente em conteúdos.

O diário de estágio de Eli, particularmente em seu primeiro semestre, se resume a poucas folhas, com pouca ocorrência de descrições mais minuciosas das aulas e das atividades que foram solicitadas pela disciplina de Prática de Ensino de Física I.

Para se ter uma idéia, falando sobre uma de suas aulas do estágio, seguia uma orientação dada pela professora da Universidade, que sugeria que os licenciandos, ao analisar suas aulas, respondessem a algumas perguntas básicas: "A minha aula foi boa por quê? A minha aula poderia ser melhor se ... Os melhores momentos da aula foram ... As minhas aprendizagens mais significativas foram ..."

Seguindo rigidamente essa orientação, Eli faz uma descrição muito sucinta de cada uma das aulas. Reduzindo toda a complexidade de uma aula a meia dúzia de palavras, dava a impressão de que fez a tarefa mais para cumprir a obrigação na disciplina da Universidade do que propriamente utilizar a oportunidade para refletir sobre suas aulas.

Ao apresentar a síntese de seu estágio, Eli escreveu um pouco mais e pudemos então perceber a emergência dos conflitos profissionais que se estabeleceram logo em suas primeiras aulas. O contexto da escola em que Eli escolheu para desenvolver seu estágio, segundo ele, era bastante desfavorável.

A escola foi fundada no início de 1968 e nesta época destinava-se a atender a população local, ou seja, a rede física. $\mathrm{Na}$ condução deste trabalho, conseguiu construir uma reputação que resiste até os dias de hoje ... Hoje, porém, já vão longe os merecimentos que construíram esta reputação, e a escola está cheia de 
grades, suas instalações são invadidas e depredadas também pelos alunos. O tal nível de que se ouve falar com saudosismo na sala dos professores é tal qual igual a muitos outros, e os professores são pressionados e desrespeitados a todo momento ...

Não vamos aqui discutir o problema da violência em nossa sociedade que se reflete naturalmente dentro de nossas escolas. Não é esse o objetivo desse trabalho.

Mas as condições contextuais que se referem Lumpe et al. [9], em apoiar o professor na sua tarefa de ensinar buscando alcançar os objetivos propostos para o ensino de ciências - que pode também ser pensada em termos do nosso contexto - não podem ser subestimadas. Condições contextuais são cruzadas no estudo de Lumpe e colaboradores com as crenças dos professores e com os objetivos da reforma do ensino de ciências. E o que se observou é que contexto hostil ou desfavorável no ambiente escolar, aliados a certos padrões de crenças dos professores, são os ingredientes essenciais para que o desenvolvimento do professor seja retardado, tornandoo desencorajado no mínimo e conformado no máximo, passando, obviamente, por casos de desistência da carreira [9].

Falando ainda de sua avaliação do estágio supervisionado, Eli começa a revelar que de fato suas crenças sobre o trabalho do professor se chocavam frontalmente com aquele contexto escolar. $\mathrm{O}$ que primeiro se evidenciou foram conflitos pessoais em relação aos seus alunos. Para ele, os alunos eram desrespeitosos, não sabiam matemática, não levavam a sério o trabalho escolar, faltavam regularmente às aulas, muitos queriam desistir, enfim, o início de trabalho de Eli conciliou os dois aspectos mais problemáticos que se referiram Lumpe e colaboradores: um contexto desfavorável e um sistema de crenças do professor Eli que se chocava frontalmente com aquele contexto.

Em julho de 1998, Eli falou retrospectivamente sobre seu primeiro semestre como professor. Foi uma conversa que classificamos como de 'desabafo', onde revelou toda a sua angústia e decepção com o início de sua profissão. Vamos então verificar algumas das considerações sobre o que foi em sua percepção o primeiro semestre como professor de física. Por vezes, ele também se remeterá ao seu trabalho na escola particular.

Em sua primeira aula na escola particular, em fevereiro de 1998, ele imaginava que fosse ter um apoio da direção da escola, que lhe prometeu isso, mas a realidade não foi bem assim. Eli começou a dar aulas, vindo de um trabalho que nada tinha a ver com educação, relatando seus primeiros momentos como professor da seguinte maneira:

Na primeira realidade [referindo-se à escola particular]eu fiz o seguinte, como eu caí de pára-quedas, né? Eu comecei em fevereiro, me deram uma sala, falaram que eu ia ter um acompanhamento, uma orientação. Apresentaram-me lá e disseram 'esse aqui vai ser o novo professor de física'. E toca o pau, né? Acompanhamento, não houve nenhum. Então, eu comecei a fazer como a gente vê o dia todo, né? Aula expositiva, normal. Tentei não bolar nenhuma nova regra. Do jeito que eles estavam, eles ficaram, e toquei a coisa do jeitão tradicional.

De fato, não podemos chamar de "início promissor", os primeiros momentos de Eli como professor. A expressão "caí de pára-quedas" é por si só reveladora de toda sua apreensão e inadaptação inicial. A partir daí, Eli começa a indicar que o conflito pessoal com seus alunos era uma das partes visíveis do des- conforto em relação ao seu trabalho. Destacava como principais problemas, em relação à sua ação docente, as dificuldades de relacionamento pessoal com seus alunos. Como atuava em duas escolas, com realidades bem distintas, em sua percepção era na escola pública de período noturno que esse conflito ganhava contornos mais dramáticos.

(...) Porque eu passo de segunda a sexta no Estado à noite. Que é esse povo briguento, duro, difícil, que você tem que ir empurrando.

E assim, Eli foi se iniciando na profissão, tentando contornar seus problemas de relacionamento com seus alunos. Não sem alguns 'arranhões', detectados por ele, tanto na escola pública quanto na escola particular. São dois episódios de problemas de relacionamento com alunos que ele analisa de maneira distinta. No primeiro, ocorrido na escola pública, ele diz ter ignorado e considerado natural o problema. Relata da seguinte maneira:

Não dá para agradar todo mundo.Tem uma aluna lá que faz um bico danado para mim. Não sei por que ela não gosta de mim. Imagino que não tenha tido nenhum problema com ela, mas não gosta de mim. Eu faço de conta que não percebo que ela não gosta de mim, e trato-a como trato a maioria. Mas ela está sempre emburradinha. Você vai insistir para ela fazer as coisas, mas ela não quer fazer. Tem aqueles para quem você 'não ata nem desata' $e$ tem aqueles que gostam de você. Tem também aqueles que acham que você está perseguindo. Aí, eu digo 'eu não lembro nem seu nome, como vou estar te perseguindo? [risos]

Um outro episódio de problemas de relacionamento com alunos que Eli nos relatou também na primeira entrevista, apresentou uma reflexão diferente sobre o acontecido. De certa maneira ele assumiu que em parte do que ocorreu houve uma participação sua, na realidade, uma dificuldade de interpretação do que estava ocorrendo. Na ocasião, nossa pergunta referia-se a algumas declarações que ele havia feito em seu diário de campo, nas quais Eli estaria se preocupando mais com aspectos de manutenção do ambiente escolar mais leve e até mais feliz. A seguir, o episódio que ocorreu na escola particular.

É duro você ter que lembrar que o aluno não gosta de sua aula. [depoimento dado com uma certa melancolia]E ele não gosta porque no começo ele não entende. Se você não olha para ele, ele acha que você também não liga e que vai passando por cima que nem um trator. Eu tive uma garotinha que chorou na aula. Eu acho que ela chorou para dizer que não estava entendendo, e eu não entendia. Eu vi uma lágrima descendo lá. Ela disfarçou e tudo mais. Mas ela estava me dizendo que não entendia, e ela é daquelas alunas boas. Só que ela é daquele lugar que não pode me xingar. [o ambiente da escola particular]Se fosse de outros lugares, ela teria me xingado. Eu acho muito desagradável! Eu acho que não consegui entender o que ela estava me dizendo!

No modelo de conflitos de Beach \& Pearson [2], Eli estaria vivendo genuinamente conflitos pessoais com seus alunos.

"Participantes se referem a conflitos e tensões em suas relações com seus alunos (...) Eles também expressam um sentimento de isolamento pessoal" [2].

A origem desse conflito, típico de professores novatos, é explicada pelo modelo de conflitos como um choque entre os sistemas de crenças do professor novato e o de seus alunos. Ao avaliar a relevância do trabalho escolar em relação a seus alunos, uma 
das possíveis conseqüências é que o relacionamento com os estudantes se deteriora por não haver concordância entre os sistemas de crenças, especialmente ao daqueles alunos que o professor novato julga ter uma baixa motivação acadêmica.

O que há de interessante nos dois últimos episódios acima descritos é a maneira como Eli lidou com o conflito. O primeiro ocorrido na escola pública, onde sua análise sobre o fato é claramente de afastamento do conflito. Naquele momento, ele considerava natural se deparar com alunos que não gostavam dele.

A análise de Eli não carrega nenhuma culpa por aquele acontecimento. Enfim, para ele, não era um problema que ele tivesse tido participação. Ele chega até a invocar sua memória para lembrar se ocorreu alguma coisa que pudesse justificar o comportamento daquela aluna que ele se referiu como "emburradinha".

O outro episódio, de dimensão equivalente, ocorre na escola particular. Tirando o fato de serem contextos diferentes, sua reação foi distinta nesse episódio. Seu depoimento, ao relatar o caso, é carregado de emoção, e o que é mais interessante: Eli se coloca como culpado na situação. Ele diz com todas as letras que não teve capacidade para compreender o porquê da aluna estar chorando, compreensão que ele só alcançou depois, elaborando os pensamentos de forma mais cabal durante a entrevista.

Embora Eli não tenha tomado nenhuma atitude naquela ocasião, há fortes evidências de que o episódio o marcou e o levou a um processo de reflexão, tendo como resultado uma mudança de qualidade fundamental na sua avaliação dos dois episódios. No primeiro caso, achou que era natural que alunos não gostassem do professor, fugindo do conflito. No segundo, percebe que, se o aluno não gosta do professor, pode ser que o professor tenha alguma contribuição para esse sentimento, assumindo, nesse caso, o conflito.

Nestes dois episódios, aparentemente corriqueiros, ocorridos mais ou menos no mesmo período, percebemos que sua posição diante do conflito não é estanque. O comportamento de Eli para lidar com seus problemas de relacionamento pessoal não é exclusivamente do nível I, dentro do modelo de conflitos. Nesse caso, ele teria que fazer o discurso de afastamento do conflito sem apresentar soluções em curto prazo. Não é genuinamente o caso de Eli. Ele admite o conflito, sofre com ele, apesar de não conseguir resolvê-lo numa perspectiva de longo prazo.

As crenças contextuais de Eli também são diferentes quando ele se refere às duas escolas. Na escola pública o aluno "pode me xingar”. É comum que não goste do professor. Já na escola particular, o comportamento de sua aluna mereceu outra consideração: o mesmo professor envolvido em episódios equivalentes, demonstra como de fato agem as crenças contextuais que referiram Lumpe et al. [9].

Pensando em termos do modelo de desenvolvimento profissional de Fuller [6] e de todos os outros modelos derivados do modelo primordial de Fuller, Eli estaria vivendo a fase de preocupação consigo mesmo, que se caracteriza por uma preocupação com sua auto-imagem e auto-adequação. Professores novatos freqüentemente relatam que não estão preparados adequadamente para se iniciar na profissão e revelam grande precupação de não conseguir apoio emocional de seus estudantes.

Para Eli, grande parte de seu conflito interpessoal com os alunos se resolveria caso houvesse uma recuperação do papel que os professores tinham no tempo em que ele era aluno do primário ou do ginásio.

Na realidade, o que Eli revelava era uma crença pessoal sobre o papel do professor calcada na imagem de uma autoridade do professor de outrora que ele não consegue reeditar. Seus conflitos de relacionamento interpessoal com seus alunos não são percebidos por ele em termos de sua inexperiência como professor. As causas do conflito se localizam fora de sua prática ou de qualquer outra variável ligada à sua performance como professor. Os alunos é que são desrespeitosos, não se encaixando em seu modelo de crença sobre como deveriam ser e agir.

Em nossa primeira entrevista, o interrogamos também sobre essa sua crença a respeito da autoridade do professor que era mais evidente em tempos anteriores e que hoje não é dada assim de maneira natural. Suas idéias sobre o tema naquele período foram do seguinte modo:

Como eu não era professor antes, só achava o que deveria ser. Não tinha uma prática de autoridade. Eu não era professor. Mas sempre acho que deveria ser assim [referindo-se ao professor ter autoridade], especialmente quando você vê aqueles filmes americanos de escolas que são uma bagunça, que você tem que entrar na escola com guarda do lado, porque é cheio de bandido. Não tem autoridade e não tem respeito. Poxa! Lugar desse não é lugar. Poderia amarrar cada um pelo pé, passar uma revista para poder entrar, né? Você lembra como era quando você estudava? Tinha que levantar para o professor entrar. Depois que ele entrava, você sentava. Você acha que esse pouco de poder e autoridade é bom.

Apesar de ter claro o modelo de autoridade do professor que considerava ideal, Eli não consegue impor seu modelo. A partir daí, constrói uma relação com seus alunos rebaixando suas expectativas, buscando sobreviver, literalmente, no sistema. Na escola pública, ter uma relação minimamente saudável com os alunos, segundo sua própria avaliação, é até uma questão de sobrevivência, de maneira que ele fica num meio termo entre não ter autoridade nenhuma e ter um mínimo de autoridade que julga necessária.

Se eu for dar um de carrasco, os alunos vão detestar não só a aula, quanto mais detestar o professor, que é pior ainda. Se gostando de você já é difícil, imaginem se não gostar. Ainda mais no Estado, onde você passa no corredor, que parece um 'corredor polonês'. Tá todo mundo no corredor.Você passa entre eles. Gostar ali é até uma questão de integridade. Eu tenho conseguido andar por lá, e o pessoal grita meu nome 'ei, professor'. É duro entrar numa sala e ter um monte de gente fazendo bico para você.

$\mathrm{Na}$ transição entre ser um aluno do programa de formação de professores e se tornar um professor real, surgem ambigüidades. É interessante que o modelo de desenvolvimento baseado nos conflitos refere-se a um comportamento, nessa transição, onde esse professor novato busca um comportamento mais próximo da perspectiva do aluno, desenvolvendo um relacionamento mais afetivo do que propriamente a posição de um professor mais distante [2].

No caso de Eli, toda essa imagem que trazia sobre a autoridade do professor, "que os alunos deveriam se levantar quando ele chegasse", não encontrou correspondência na realidade. Interessante é que, mesmo estando na situação de aluno da licenciatura, suas crenças sobre o papel do professor estavam inicialmente na direção de um professor com a autoridade de tempos de outrora, contrariamente a uma postura de se aproximar mais afetivamente 
dos alunos.

(...) Você não tem nenhuma experiência de lidar com pessoas, nem com pessoas 'uma', nem com pessoas 'quarenta'. Então, enquanto você não tem isso, você vai para a sala de aula e não é um professor que vai lá, vai uma pessoa que sabe fazer exercícios, mas ele não é professor, especialmente aqueles que são mais novos, caras de garoto ... Ao pegar uma classe que tem mais de 20, 30, vira uma zona, né? Além disso, entender o lado do aluno, né? Porque quando você é bem-sucedido[como aluno] acha que 'não é tão difícil assim'.Você nunca teve um espaço para pensar porque as pessoas não entendem, porque o outro não entende ... Então, eu não acredito que alguém que vá lá para a aula e nunca tenha feito matérias reflexivas assim, seja um professor [referindo-se às disciplinas pedagógicas da licenciatura].

Adams \& Krockover [1] afirmaram que o professor novato está tipicamente preocupado com sua sobrevivência na sala de aula. Para sobreviver, necessariamente, o professor tem que proceder a uma checagem nas suas crenças pessoais sobre o trabalho escolar, sejam ajustes de curto prazo, chamados de "técnica de sobrevivência”, ou de longo prazo, junto ao sistema de crenças, buscando lidar com os conflitos emergentes.

De fato, o que apenas se insinuava como pequenos ajustes nas estratégias de Eli, quando lidava com seu conflito de relacionamento pessoal com seus alunos, vemos que, na constituição de seu papel de professor, as mudanças são mais evidentes.

Aquela visão de um professor com mais poderes e mais distante dos alunos realmente se desvanece no seu primeiro ano como professor, embora surja uma imagem caótica da profissão, na avaliação de Eli, que, já não tendo tantos poderes, também não representa um profissional bem sucedido aos olhos dos alunos.

Do ponto de vista da construção de seu papel como professor numa perspectiva de aproximação com seus alunos em termos cognitivos, nesse caso, levando em consideração as idéias de seus alunos e agindo mais como um interrogador do conhecimento do que como um professor que detêm o monopólio do conhecimento, Eli opta por ser um professor tradicional. Suas aulas, segundo o que ele próprio relata, seguem a rotina de apresentação do conteúdo pelo professor como eixo de sua aula. Em seguida, como tradicionalmente se faz, propõe exercícios de fixação. Enfim, o papel que Eli desenvolveu em seu primeiro semestre como professor é genuinamente o de um professor tradicional.

Dentro do modelo de desenvolvimento profissional em fases de preocupações, o primeiro semestre de Eli o colocava na fase de preocupações consigo mesmo no que tange à sua definição de papel como professor. Publicamente, se dizia preocupado com seus alunos, mas na realidade estava preocupado com sua própria performance, sua própria imagem, sua adequação [6-8,14].

Eli viveu em seu primeiro semestre como professor de física todos os conflitos previstos na tipologia proposta por Beach \& Pearson [2].

Também em nossa primeira entrevista, detectamos a emergência de conflitos instrucionais em sua prática. Logo que Eli chegou para dar aulas na escola particular, suas opções instrucionais foram questionadas pelos alunos. Naquela realidade, ele dizia que os alunos queriam "aprender física sem sofrimento", mas já nas suas primeiras aulas surgiram problemas com a condução de suas aulas, que seguiam o formato tradicional de apresentação dos conceitos e resolução de exercícios.

Conflitos instrucionais surgem quando há um descompasso entre o que o professor novato considera como relevante do ponto de vista acadêmico e a falta de interesse dos estudantes a essa visão.

"Planejam com cuidado a instrução, mas os estudantes não respondem como desejariam. Entre o que consideram importante e a falta de interesse dos estudantes a essas atividades. Entre seu próprio currículo e o currículo oficial [2]."

Foi exatamente o que ocorreu com Eli em suas primeiras aulas. Diante de sua percepção de que tinha que "tocar a aula do jeitão tradicional”, "sem fazer grandes mudanças", "como sempre ocorreu”, encontrou alunos que não responderam como esperava ao desenvolvimento de sua instrução.

(...) Daí, fui fazendo trabalhos em grupos, grupos pequenos, grupos grandes. Fazendo aula do tipo "oficina de exercícios". Então, eu fazia uma exposição, tentando fazer com que eles entrassem em contato com a matéria que eu estava lecionando. Depois fazia oficinas, né? E aí, eu ficava circulando entre eles para tentar resolver. Muita gente não gostou muito. Eles preferiam que eu fizesse como todo mundo:trouxesse os exercícios prontos, colocasse na lousa e eles copiassem. Queriam ainda que na prova eu escolhesse um daqueles. Do jeito que eu estou fazendo, eles têm que fazer um monte de exercícios, e as dúvidas vêm, surgindo a angústia de não saber. Tem gente que fica triste porque parece que não está entendendo, embora estejam entendendo muito mais do que outras coisas. A diferença é que eles são expostos a exercícios de nivel difícil e toda hora eles se vêem frente a coisas que não conseguem fazer. Eu preciso dar uma ajudazinha, uma ajuda aqui, uma ajuda ali. Acho que eles não perceberam que estão entendendo bastante até. Essas são turmas pequenas. Então, por causa da reclamação, eu tive que dar uma ajeitadinha, me deter mais com exemplos, tentando chegar mais perto do que eles queriam, sem abandonar o que eu gostaria de fazer e sem abrir mão de alguma coisa que eu acho importante. Eu pedi um diagnóstico do que eles achavam das aulas, do que eles gostariam que acontecesse e do que eles gostam. resumo foi que eles não gostavm de fazer os trabalhos que eu dava.

Eli tinha uma crença sobre o ensino de física em que o aluno tem que resolver grandes quantidades de exercícios após uma exposição sua em que ele aborda os conceitos em seus aspectos formais. Logo de saída, os alunos reclamaram dessa condução, o que o fez realizar pequenos ajustes. Em suas próprias palavras, diz que "teve que dar uma ajeitadinha", "se deter mais em exemplos”, enfim, a pequenos ajustes que em nada modificavam sua visão de ensino baseada em transmissão de conhecimento e treinamento para resolução de exercícios. "Oficina de exercícios" é um eufemismo que ele utilizou para dizer que seus alunos tinham que se alinhar com suas crenças de que aprender física passava por resolver grandes quantidades de exercícios.

Ao dar uma "ajeitadinha" na condução de sua instrução sem abrir mão do que era fundamental em suas crenças sobre o ensino e a aprendizagem em física, Eli vai conformando estratégias de enfrentamento do tipo I e do tipo II. Vai perdendo os anéis para não perder os dedos, como afirma o dito popular. Percebe o conflito. Por vezes, impõe de maneira integral suas crenças de seguir a velha rota de teoria/exercício/exercício/teoria ... Outras vezes, para sobreviver, faz pequenos ajustes de curto alcance, muda o nome 
da atividade de resolução de exercício, mas não o que considera fundamental.

Dentro do modelo de desenvolvimento do professor em fases, de Fuller, da mesma forma como nos outros conflitos, Eli estaria vivendo preocupações típicas da fase de preocupações consigo mesmo. Professores nessa fase revelam preocupação com suas habilidades para entender e manejar de forma adequada os conteúdos.

O importante não é saber o conteúdo, mas transformá-lo em conteúdos ensináveis ou, como disse Shulman (1986), transformar o conhecimento de conteúdo em conhecimento de conteúdo pedagógico.

Já Mellado [10], que também se apoia nessas idéias de Shulman, fala em desenvolvimento dos componentes profissionais dos professores de ciências: do conhecimento estático acadêmico para o desenvolvimento profissional do conhecimento de conteúdo pedagógico. Portanto, não basta saber. Tem que saber ensinar!

Também detectamos conflitos institucionais ou contextuais na prática de Eli durante o seu primeiro semestre de ensino. Nesse caso, configura-se um conflito que se define por uma pressão para que o professor novato se adapte à cultura escolar e às expectativas do programa de formação.

"Participantes experimentam conflitos e tensões relacionados à expectativa do programa da Universidade, à complexidade e política do sistema escolar e pressão para se socializar com a cultura da escola e do ensino [2]."

Os depoimentos de Eli indicavam que naquele período ele sentia um choque na sua tentativa de entender e se adaptar ao sistema escolar. Ao contrapor as realidades da escola particular e da escola pública, ele revelava sua insatisfação com o que considerava um sistema injusto na escola pública.

(...) É ao contrário no Estado. [contrapondo com a realidade da escola particular]Você não tem essa autoridade. Qualquer coisa que você faça, ou reclame, ou não resolva, ou peça para alguém resolver, te desmerecem e pesa contra a sua avaliação no final do ano. Se você tiver problema com algum aluno, você tem que dar um jeito e resolver. Se não, você tem uma reunião com o diretor e ele coloca 'menos' para você na avaliação ...

Essa sua posição de desconforto em relação ao que considerava como política da escola pública ficou mais evidente quando oportunizamos um espaço para que revelasse suas crenças sobre o que ele consideraria como um professor bem sucedido na escola pública:

Com esse pessoal todo ... seria no mínimo que eles passassem a detestar menos. Passassem a entender que aquilo faz parte do mundo de verdade. [falando do ensino de física]Passar de ano ... todo mundo vai passar mesmo. É proibido repetir. Se o cara ficar até por falta, ele faz trabalho de reposição e passa. Ser bem sucedido no Estado é difícil ... talvez não exista nenhuma cobrança do que é ser bem sucedido. Se você não faz inimigos, não briga como diretor e resolve seus problemas na sala, você tem uma avaliação boa. Daí a ser bem sucedido ... Se o aluno aprende ou não ... ninguém vai olhar. Talvez ser bem sucedido seja só uma satisfação pessoal de perceber que alguém entende o que você fala.

Há, de fato, um conflito em Eli em relação à maneira com que julga estar organizada a escola pública: um flagrante descompasso entre suas crenças sobre o sistema escolar e o que pode perceber nos seus primeiros momentos como professor.
Quanto à expectativa do curso de licenciatura na Universidade, diante do qual o modelo de conflitos chama complexidade do sistema escolar, Eli também desenvolve conflitos institucionais nesse aspecto.

Em um dos raros momentos em que descreve em seu diário com mais cuidado suas percepções da expectativa da Universidade em termos da realidade escolar que vivia, Eli mostra que de fato via as contribuições da licenciatura como distantes da realidade escolar. Escreveu isso em seu diário, a propósito de uma atividade solicitada pela disciplina de Prática de Ensino de Física I que envolvia a leitura de um texto sobre o ensino de física [17]. Este texto, de crítica ao ensino tradicional, enumera vários pressupostos nos quais se baseia a perspectiva do ensino tradicional de física, buscando desmontar cada um desses pressupostos. Os comentários de Eli, na ocasião, mostravam esse seu conflito em que a expectativa da Universidade ia numa direção e suas crenças sobre o trabalho escolar em outra direção. Suas ponderações são reveladoras:

Nós professores elou alunos preferimos nos enquadrar em um ou mais desses pressupostos (do ensino tradicional de física) por comodidade elou até mesmo por covardia ou ignorância. Viemos e somos filhos desse esquema, e nele nos sentimos mais seguros. Isto é bom para o ensino? Acredito realmente que não, porém as mudanças são difíceis de se operar mesmo em um único indivíduo, imagine só em uma comunidade.

De maneira que, na prática de Eli em relação aos conflitos tipicamente institucionais, revela-se tanto em relação à sua adaptação à cultura escolar quanto às expectativas da licenciatura. Mas como em todos os outros conflitos, Eli não tem força para lutar contra o que considera um sistema injusto. Então, ele faz pequenos ajustes, evita entrar em atrito com seus alunos, tenta dar aula apenas aos alunos interessados, enfim tenta sobreviver num sistema que considera hostil e inadequado. Quanto às suas percepções da expectativa da licenciatura faz o discurso que percebemos em grande parte de seus colegas: somos filhos desse sistema, mudar é muito difícil!

Usava também nesses casos o efeito filtro, que se referiram Kagan [8] e Pajares [12], para manter o mais intacto possível seu sistema de crenças, evitando, assim, fazer uma consideração mais radical das expectativas da licenciatura. O efeito filtro pode ser entendido como um "filtro" que é utilizado pelo professor nos cursos de formação inicial para selecionar as contribuições que derivam do programa. Esse filtro é apoiado nas crenças educacionais que dirigem a aceitação das orientações do programa, ou as rejeitam, em favor da manutenção da integridade do sistema de crenças.

Dentro do modelo de desenvolvimento profissional em fases, novamente como nos outros conflitos, Eli estaria vivendo exclusivamente preocupações consigo mesmo. Neste caso, de suas preocupações com a política escolar e com a expectativa da licenciatura em física, os modelos se referem às preocupações em que o professor novato tenta estimar o quanto pode suportar das pressões vindas do staff escolar - diretor, outros professores, alunos. Também o professor novato está preocupado com o estabelecimento dos limites de sua aceitação profissional dentro da escola e sua construção das relações de trabalho. 


\section{Segundo semestre de Eli como pro- fessor: Sua participação nas dis- cussões da Prática de Ensino de Física II}

Quanto às contribuições como fonte de dados, vindas de seu diário de estágio, no segundo semestre, para o entendimento de seu desenvolvimento profissional, novamente nos deparamos com o problema detectado no primeiro semestre.

O diário de estágio de Eli contempla, com anotações, todas as atividades solicitadas pela disciplina de Prática de Ensino de Física II. Porém, seus comentários são lacônicos e sugerem novamente que ele cumpriu com sua obrigação de 'aluno', raras vezes fazendo comentários mais longos e considerações mais amplas de seu trabalho e das atividades sugeridas pela disciplina. De maneira que quase não utilizaremos dados vindos de seu diário, nos voltando mais às suas intervenções no âmbito da disciplina de Prática de Ensino II que, como já dissemos, tivemos a oportunidade de graválas em sua totalidade. Por fim, para compor o quadro completo de todo o período que estivemos mais próximos do trabalho de Eli, analisaremos algumas de suas percepções retiradas de nossa segunda entrevista.

Eli era um licenciando que não se colocava com muita freqüência nas discussões gerais da disciplina de Prática de Ensino de Física. Raras foram as vezes em que ele espontaneamente iniciou uma discussão ou argumentou de maneira mais extensa sobre qualquer aspecto que se discutisse durante as aulas. Já dentro dos trabalhos em grupo, quando ocorriam, se colocava com muito mais desenvoltura, argumentando longamente e defendendo seus pontos de vista com vigor.

Curiosamente em duas aulas, das 18 aulas do semestre, que consideramos momentos- chave, quando houve trabalhos em grupos e pudemos então observar com mais detalhes os pensamentos de Eli, estava no grupo de nosso outro sujeito de pesquisa Ani [18]. Isso ocorreu em primeiro lugar porque Ani era amiga pessoal de Eli, embora tivessem pontos de vista totalmente divergentes em relação ao ensino de física. Em segundo lugar, porque durante o segundo semestre estavam coincidentemente dentro do grupo de cinemática, o que os levou a ficarem no mesmo grupo na aula de encerramento de Prática de Ensino de Física I no final de junho e também naquela discussão realizada no meio de setembro, em que discutiram criticamente o conteúdo de cinemática.

Naquela aula de encerramento do primeiro semestre, ao final de junho, Eli formou um grupo com três outros colegas seus para fazer uma avaliação final da disciplina, em que a professora da Universidade solicitava que discutissem e registrassem por escrito suas posições sobre os conceitos de ensino e aprendizagem em física no âmbito do Ensino Médio, resgatando, quando necessário, as contribuições que receberam da disciplina durante o primeiro semestre.

Como essa aula se refere ao final do mês de junho, muito próxima portanto de nossa primeira entrevista que se deu em julho, veremos que as posições de Eli se sustentavam no fundamental, como era de se esperar. De maneira que os episódios dessa discussão apenas servirão para confirmar e completar alguns aspectos das crenças de Eli. Ao cruzar esses dados de fontes diferentes e de períodos quase simultâneos, estamos buscando observar a consistência de nossas análises sobre o desenvolvimento de Eli em seu primeiro semestre como professor.

O grupo iniciou a discussão buscando responder à questão "o que é ensinar física?"

O comportamento de Eli, como dissemos naquela ocasião, era marcado pelo pragmatismo, ao passo que as posições de Ani, buscavam discutir com mais profundidade as perguntas solicitadas. Querendo já formular uma resposta para a primeira pergunta da atividade de final de semestre proposta pela disciplina. Após breve discussão, Eli propôs logo uma redação.

Então nossa definição ficou assim: ensinar é tudo aquilo que o professor faz com o objetivo de passar o conteúdo ...

De fato essa definição, que propunha Eli para a questão do que significava o ensino de física, levou àquela polêmica toda, que revela a "marotice" de alguns professores do pré-serviço que, por vezes, se comportam como alunos e outras vezes se comportam como professores, ou se lembram que serão futuros professores. Tentam utilizar expressões, na redação de seus trabalhos acadêmicos na Universidade, dentro das disciplinas do núcleo da Educação, que sabem que agradará os professores formadores. É como se tivessem um banco de palavras que podem lançar mão em situações adequadas com o claro objetivo de ir ao encontro à expectativa da licenciatura e logicamente serem recompensados com notas, ou seja, agem, nesses casos, estritamente como alunos.

Não foi o caso naquela ocasião nem de Eli, tampouco de Ani. A formulação proposta por Eli apenas refletia fielmente suas crenças do que para ele seria ensinar física: "passar o conteúdo". Nenhuma novidade no perfil que estamos construindo de seu desenvolvimento. Ele optou por ser um professor do tipo tradicional que tinha como eixo central de sua instrução "passar conteúdo". Em seguida, aceitando a brincadeira de alinhar a resposta à expectativa da disciplina, faz uma outra formulação que falava em "fazer o aluno se apropriar do conhecimento" e tudo mais, porém as imagens daquele momento são inequívocas. Eli estava realmente brincando.

De fato os núcleos de preocupação de Eli e Ani são frontalmente divergentes. Eli vai apenas reafirmando o que vinha falando desde o início do primeiro semestre. Vai durante todo o tempo se queixando de seus alunos, de que eles "não conseguem fazer contas simples", de que ele passa "dois meses ensinando velocidade média e os alunos não aprendem”. Enfim, novamente reafirma a adequação de nossa análise, até então, que apontava que Eli em seu primeiro semestre como professor vivia exclusivamente preocupações da fase de preocupações consigo mesmo.

Agora o grupo se empenhava em responder "o que é aprender?" e "quando se pode dizer que aprendeu?"

Seguindo a mesma dinâmica, onde dentro do grupo se destacavam as opiniões de Eli e Ani, os quatro licenciandos continuavam a discutir a atividade de final de semestre proposta.

A polarização nesse caso foi bastante interessante desde o início, quando Ani dizia que aprender lhe sugeria a idéia de mudança. Eli, não concordando com essa visão, apresentava a argumentação de que aprendizagem estaria ligada a uma idéia de utilidade. Ele dizia que "você aprende sempre que você consegue usar". Eli insistia na idéia mais utilitarista de aprendizagem. 
Minha resposta sobre o que é aprender é: o camarada que aprendeu é o camarada que consegue fazer. Propõe soluções. Se é um cara que aprendeu um pensamento lógico, ele consegue olhar para um texto ou qualquer situação e organizar esse negócio. Não importa se está certo ou errado. Se ele consegue juntar as coisas que você transmitiu para ele e propor soluções, eu acho que ele aprendeu.

O estilo de ensino que Eli estava desenvolvendo se enquadrava, naquela ocasião, perfeitamente na definição de Simmons et al. [15], quando definiam o estilo de ensino centrado no professor.

"Estilo de ensino centrado no professor, definido como crenças e ações nos quais o professor é o condutor chefe da maior parte do conhecimento do conteúdo a ser transmitido para os alunos, tem responsabilidade para organizar e entregar [deliver] o conhecimento de conteúdo para os alunos ... Enfatiza o método científico ou algoritmos matemáticos e aprendizagem mecânica, empregando método de instrução dirigida pelo professor com quase nenhuma interferência dos estudantes" [15] (grifos nossos).

Já Ani falava em aprendizagem ligada a sentimentos, que não era só um empreendimento racional. Chegou até a falar em "paixão" pela aprendizagem. Obviamente o desconforto entre Eli e Ani era flagrante. Embora fossem amigos, seus focos de preocupação eram distintos, porque suas crenças sobre ensino e aprendizagem em física também eram distintas. Quando Ani enunciou sua visão de aprendizagem como algo que pode não estar apenas no campo da racionalidade, a discussão se acirrou.

(...) Por isso eu questiono um pouco essa coisa de aprender só para resolver problema. Eu concordo que existe muito disso, porque você está mediando uma relação entre um problema com alguma coisa que você sabe e está juntando as duas coisas. Mas será que é só isso? [ironizando] Acho que aprender está ligado a sentimento. Acho que aprender não é uma coisa só racional.

Para Eli, esse novo elemento sentimental, colocado por Ani para definir aprendizagem, não era de forma nenhuma pertinente, o que já de alguma maneira era esperado e coerentemente se encaixava no todo de seu pensamento. Continuava ele tentando propor uma redação para a questão da aprendizagem que ia na direção que "aprender é dominar o conceito e conseguir manipulá-lo".

Para um professor que acreditava num estilo de ensino centrado no professor, no qual aprendizagem era essencialmente mecânica e que vinha de fora para dentro do aprendiz, falar em sentimento na aprendizagem era algo totalmente fora de propósito. Ani usou então, pela primeira vez, o conceito de desestruturação no contexto de uma tentativa de superação do indivíduo para aprender. Assim enunciou sua posição:

Eu vejo as coisas de uma maneira mais profunda (...) A gente não aprende simplesmente o conteúdo. Eu acho que, toda a vez que vai aprender alguma coisa, você está se confrontando [tem uma parte do depoimento que está inaudível]. Você nunca gosta de estar nessa situação. Acho que tem que assumir esse papel de estar numa situação difícil, que não domina aquilo e ter vontade de superá-la. Ou seja, você tem uma desestruturação.

A partir dessa formulação de Ani, que incluiu o conceito de desestruturação, ocorreu uma confusão de significados entre Eli e Ani, que parecia sugerir que Eli não sabia o que significava o conceito de desestruturação, quando referindo-se à aprendizagem. Se desestruturação para Ani era uma situação difícil, mas necessária para que houvesse uma aprendizagem de fato, para Eli desestruturação era sinônimo de destruição.

Desestruturação é uma coisa chata. Pelo que eu sei, antes de entrar para a escola, ele entrou para a vida. Errado ou não, o mundo continua sendo o que eu sei. Tanto é verdade que dá certo, ela [uma criança qualquer] joga bola [Não dá para ouvir direito. Eli parece que fala sobre o fato de que essa criança joga futebol e usa conceitos da física sem refletir] ...eu acho que é mais de complementação do que de destruição.

Eram duas pessoas defendendo suas crenças. Eli, estando na fase de preocupações consigo mesmo, querendo reafirmar suas crenças gestadas em períodos anteriores à sua entrada no programa, que apontava um estilo de ensino mais centrado no professor, como descreveram com propriedade Simmons e colaboradores. Ao passo que Ani vivia algumas preocupações ainda do campo de preocupações consigo mesmo, mas, sobretudo, vinha se desenvolvendo de maneira a indicar que suas preocupações se colocavam substancialmente dentro do campo de preocupações com os alunos, uma fase posterior ao que vivia naquele momento o nosso protagonista Eli.

No meio de setembro, na sexta aula de Prática de Ensino de Física II, novamente tivemos uma grande oportunidade de investigar mais de perto as crenças de Eli. Através de uma atividade em grupo, a propósito de uma discussão anterior na disciplina que falava sobre o ensino construtivista da velocidade angular, apoiando-se no trabalho de Silva [4], formaram-se novamente os grupos de licenciandos que naquela ocasião estavam divididos conforme os grandes tópicos dos conteúdos de física do Ensino Médio: grupo de cinemática, grupo de óptica, grupo de eletricidade e grupo de termodinâmica.

Optamos novamente por gravar o desenvolvimento da discussão do grupo de cinemática, que contava com as presenças de Eli, Ani e outros dois licenciandos.

Basicamente a discussão dentro do grupo se remeteu a considerações críticas dos conteúdos de cinemática no Ensino Médio, a forma como esses conteúdos são ensinados tradicionalmente nas escolas, mas, principalmente, as visões que cada um dos integrantes do grupo tinha sobre a melhor forma de se ensinar cinemática, o que fugia totalmente da proposta indicada pela professora da Universidade, que sugeria que embasassem a discussão no trabalho de Silva [4], que havia sido abordado em uma aula anterior.

As posições de Eli e Ani mantiveram o antagonismo que se revelou naquela discussão do final de junho.

As posições de Eli se mantinham inalteradas. Para ele, o conteúdo de cinemática tinha que ser ensinado logo no início do Ensino Médio, como sempre ocorreu, e mais do que isso: da mesma forma que sempre se desenvolveu. Já Ani questionava tanto a obrigatoriedade de se ensinar cinemática logo no início do Ensino Médio quanto a forma extremamente matematizada que esse conteúdo era tratado. Eli se dizia decepcionado com a baixa motivação acadêmica de seus alunos para aprenderem cinemática, já que para ele esses conceitos faziam parte do dia-a-dia das pessoas que se movimentavam e do movimento dos corpos em geral. Por essa sua visão é que naquela ocasião do final de junho, quando discutiam aprendizagem em física, Eli acreditava que para os alunos formalizarem os conceitos de cinemática bastava ape- 
nas complementar o que já sabiam intuitivamente de seu próprio cotidiano. Por outro lado, Ani considerava também o conteúdo de cinemática na forma como é tradicionalmente ensinado como "muito chato" e que deveria se usar mais história da ciência para justificá-lo.

Eli mostrava na discussão que realmente tinha preocupações com o conteúdo de cinemática no sentido de não entender o porquê seus alunos tinham tanta dificuldade. Dizia na ocasião que já havia feito algumas tentativas para melhorar suas aulas de cinemática, como levá-los para o pátio e tentar dar uma aula de movimento fora da sala de aula. Suas impressões sobre essa experiência não foram as melhores. Para ele, os alunos "só queriam matar aula", "fazer bagunça”. Assim, ele reafirmava que cinemática tinha que ser ensinada do jeito como ele próprio aprendeu: montando, resolvendo equações horárias do movimento e fazendo gráficos e interpretando esses gráficos.

Ani achava que o conteúdo de cinemática seria uma oportunidade para estudar a história da física, contando as contribuições de Galileu e seu contexto histórico no desenvolvimento dessa ciência. Percebia que seus alunos tinham idéias intuitivas sobre movimento, mas a passagem dessas idéias intuitivas para a formalização matemática dos conceitos era muito problemática.

Durante toda a discussão observamos a repetição do contraste das posições de Eli e de Ani. Eli, mais conservador, partia da idéia de que não se podia fugir do que estava determinado. Relatava que na semana seguinte faria uma prova para seus alunos sobre o conteúdo de cinemática e dizia "Os caras têm que aprender a fazer. Não dá para ficar com muita graça”. Ironizava as posições de Ani, dizendo que ela queria dar uma "enfeitadinha" na cinemática. Eli não percebia que as diferenças entre ele e Ani eram mais profundas do que simplesmente uma "enfeitadinha".

Enfim, dois sujeitos, duas formas distintas de pensar o ensino de física.

Eli demonstrava cabalmente ser um professor preso às dificuldades de seu trabalho. Diante disso, ao invés de pensar em mudanças, reafirmava posições conservadoras de ensino. Desses episódios, confirmamos a análise que estamos fazendo do desenvolvimento de Eli. Ele dá um status epistemológico ao conteúdo de cinemática assim como a todos os outros conteúdos tradicionalmente trabalhados no ensino de física do nível médio - um valor fundamental. Não cogita, como sugere Mellado [10], dar uma consideração epistemológica equivalente às pré-concepções de seus alunos, tampouco considerá-las do ponto de vista didático apenas. Ou seja, na visão de um professor que desenvolvia crenças no ensino centrado no professor, nada teria que mudar, nem a cinemática, nem nenhum outro conteúdo, tampouco as formas de ensinar.

Mas o que chama a atenção é que ele próprio tinha evidências de que seus alunos possuíam concepções intuitivas de movimento, mas se indignava quando eles não conseguiam fazer a ponte entre essas suas concepções intuitivas e a formalização dos conceitos da cinemática.

"Crenças são formadas bem cedo e tendem a se autoperpetuar, perseverar, mesmo contra contradições causadas pela razão, tempo, escolaridade ou experiência" [12].

$\mathrm{Na}$ segunda entrevista que realizamos com Eli em maio de 1999, ele já não mais trabalhava como professor daquelas duas es- colas. E uma das perguntas dessa nossa conversa foi justamente para que ele falasse a sua versão sobre a saída das escolas.

$\mathrm{Na}$ estadual [escola pública noturna]foi automática. Como você não é habilitado, no final do ano, perde automaticamente a vaga e tem que voltar para a escola em dia de atribuição e aí, conforme os pontos, você fica ou não. É independentemente de terem gostado de você ou não. Na escola particular já tem. Lá disseram que estavam fazendo um rearranjo financeiro. Como tem menos pessoas, então tem menos encargos. Pode ser que sim, pode ser que não. É o que acontece em times de futebol. O time não vai muito bem, manda o técnico embora, melhor.

Interessante que quase um ano depois de nossa primeira entrevista o discurso de Eli tinha os mesmos elementos. Ele continuava a se queixar da escola, dos alunos, do salário do professor, do desprestígio da carreira. Naquele momento, ele estava dando aulas no período noturno de um curso supletivo público na mesma região em que sempre trabalhou. Sobre suas relações interpessoais com os seus novos alunos, ele explicou que estão mais amenizadas, principalmente devido às características da escola e dos alunos.

É um curso de supletivo. Vinte aulas por semana, quatro aulas por noite. Só que todas as pessoas são mais velhas. E elas têm, com algumas exceções, mais que 25 anos ... Os caras têm 20 anos que não estudam. Não sabem somar, não sabem tabuada ... Têm todos os problemas normais como se fossem adolescentes. A diferença, são boas diferenças. É que eles não estão indo porque são obrigados. Alguns até que vão porque precisam do diploma para a firma, e coisa e tal. Alguns até pensam em fazer um curso superior depois, principalmente os mais novos. Os mais velhos estão indo porque estão indo. Não têm pai mandando. Se ele não quiser ir, ele pára e pronto. Depois que eles são velhos, então, não fazem parte daquela turma do 'eu posso tudo', 'vamos fazer uma bagunça'. Os caras trabalharam o dia inteiro. Têm consciência disso, o que o adolescente não tem. Então vão lá para aproveitar mais.

Se seu conflito pessoal nessa situação concreta está mais amenizado, não é porque ele refez sua análise, e sim porque mudou o perfil de seus alunos. Alunos mais velhos se aproximam mais de sua crença de como devem ser os alunos em geral. É uma situação que lembra um pouco as relações pessoais que ele dizia serem mais amenas com seus alunos da escola particular no início de sua carreira, em 1998, embora naquele caso se tratasse de um público adolescente.

Novamente aqui valem as observações feitas por Lumpe et al. [9] sobre as crenças contextuais desenvolvidas por Eli. Tanto naquela escola particular, em que iniciou na profissão, como nessa nova escola, suas percepções do contexto são distintas daquela que tinha em sua primeira escola pública.

O que muda no fundamental não são as crenças sobre suas relações interpessoais com seus alunos. Mudam os contextos. De maneira que em contextos que ele considera mais favoráveis, seus conflitos ficam mais amenizados. Entretanto, apesar de mais amenos, seus conflitos com seus novos alunos não são resolvidos.

Durante a segunda entrevista, motivados pela sua insistência em se referir à escola do passado, ao professor de antigamente, aos alunos de antes, perguntamos se ele não estava sempre se debatendo entre o passado e o presente da escola. Para responder a essa questão, Eli novamente apresenta o problema de relacionamento 
com seus alunos como central, englobando todos os outros problemas relacionados com o ensino de física.

$\mathrm{Na}$ medida em que a figura de professor de Eli vê diminuída sua importância, a imagem do aluno de Eli ganha poderes extraordinários.

Aí, se você for pensar em como ensinar física, tem todas aquelas coisas que trabalhar... concepções prévias, que daria trabalho, tendo o cara a condição social que tivesse. Mas a dificuldade de tocar a aula passa longe, está passando longe do problema técnico, muito mais perto do problema social e de relacionamento. Eu estou fazendo agora estágio de matemática. O professor [da escola onde ele desenvolve o estágio da Prática de Ensino de Matemática] deve estar ficando louco, porque lá eu sou ouvinte. Vou lá olhar. Garotos de 11 a 12 anos, eu diria que têm $70 \%$, ficam em pé o tempo todo. Têm que estudar matemática e o cara não consegue que as pessoas sentem e tentem trabalhar. Não tem respeito. $O$ aluno sabe que o professor não pode encostar a mão nele. Não é bater não. Encostar a mão nele, o cara não pode. O aluno entupido de direitos, qualquer reclamação de aluno, que pode entrar com um processo porque o professor não fez tal coisa, ele tem que provar. Tem que perder dias, ir lá. E antes tinha um outro poder. $O$ aluno tinha menos direitos. Então o aluno se preocupava em fazer porque reclamar não adiantava muito. Hoje você tem 40 caras cheios de direitos contra um só. Você vê o professor enlouquecendo. É difícil dar aulas. Não é nem que é difícil fazer o cara entender, porque, se você o faz sentar e trabalhar, o cara aprende. O duro é fazê-lo sentar. Aífalam que a gente tem que tentar um outro processo de ensinar. Eu tô pensando como vou ensinar equação de primeiro grau se ele não sentar e fizer algum dia. Eu posso cortar papel, plantar bananeira, qualquer coisa. Mas um dia ele vai ter que ler o texto e transformar aquilo numa linguagem matemática. Isso só acontece com ele. Tem que ler e transformar. Tem que sentir dificuldade, tem que fazer. Mas se você não consegue botar o cara sentado, ele não te respeita, não respeita as regras da escola.

O desenvolvimento de Eli nesse quase um ano e meio em que o acompanhamos mais de perto não deixa margem de dúvida sobre o que o afligia. Poderíamos destacar mais uma grande quantidade de fragmentos de seu pensamento que apoiariam de maneira inequívoca o fato dele se sentir extraordinariamente incomodado com as relações pessoais que se estabeleceram entre ele e os alunos em suas aulas de física. A figura do aluno nas crenças de Eli deve ser daquele aluno respeitoso acima de tudo. Aprender física é algo que se alcança com os alunos trabalhando ordeiramente em sala de aula.

Se o professor for respeitado, o ensino ocorre por transmissão de conhecimento da maneira que naturalmente sempre aconteceu, e, o aprendizado, de forma mecânica pelo treinamento. Mas a realidade se nega a apoiá-lo, e assim Eli vai construindo sua profissão, não sem acumular grandes frustrações e sem tampouco ter em seu arsenal de habilidades formas eficazes de reflexão que o auxiliem a lidar com seus conflitos.

Dentro do modelo de desenvolvimento profissional baseado nos conflitos, ao tratar os conflitos de relacionamento com seus alunos, usa estratégias de enfrentamento dos níveis I e II. Se as condições contextuais lhe forem favoráveis, tentará impor integralmente suas crenças sobre o que deve ser o relacionamento professor/aluno. Se o contexto lhe for desfavorável, debitará nas perfor- mances dos alunos as razões de seus conflitos interpessoais. Nesse caso, pode fazer pequenos ajustes em seu sistema de crenças que se enquadram nas ações utilizadas pela estratégia de enfrentamento de conflitos do tipo II [2].

Também em nossa segunda entrevista pudemos observar o desenvolvimento de Eli em relação à forma como lidou com seus conflitos de papel como professor que detectamos em seu primeiro semestre. Naquele momento, Eli já estava caminhando pelo seu segundo ano como professor e imagens de uma profissão desprestigiada povoava o seu discurso. Perguntamos se ele acreditava realmente que os alunos pudessem chegar a ter uma imagem tão denegrida da profissão de professor, chegando a dizer "professor eu não quero ser!", como o próprio Eli sugeriu em um determinado momento de nossa conversa.

Professor de jeito nenhum! Primeiro, que dar aula é duro. Olha só essa gente em volta. O cara sabe disso. Ele sabe que ele, os amigos, sabem que é difícil trabalhar o dia inteiro com aquela tropa. E outro que paga pouco. Então, o grande desinteresse começa aí. Foi o tempo em que você olhava para o professor e dizia: 'olha eu queria ser assim', 'olha quanta coisa ele sabe', 'e essas coisas que ele sabe, ainda por cima, podem dar o padrão de vida que eu quero ter'. Isso não acontece mais. Então, a dificuldade de dar aulas, uma grande parte da dificuldade tá aí.

Eli vai construindo seu papel de professor marcado pela decepção e com uma visão de uma profissão extremamente desprestigiada. Como durante todo seu discurso ele sempre se referiu ao status da escola e do professor de tempos passados, nos perguntamos se ele não estaria muito preso ao passado e que por isso se frustrasse muito no presente.

Não é o passado da escola. Não interessa se a escola prestava ou não. Se uma pessoa que não vale nada para você, então o que ela fala vale pouco também. Se alguém te dá um conselho e você acha que ele é idiota, pra que serve esse conselho? Se o cara te dá um conselho e em alguma coisa ele é ídolo para você, se o cara é pra você uma qualidade, o que ele fala vale. Se você olha essa situação [apontando para as imagens de sua aula, que estava sendo exibida] porta de aço ... essas coisas assim, dinheiro é uma recompensa. Quando você olha para um cara [apontando uma cena de sua aula], esse aí tá até bem vestidinho, mas você olha pro camarada mal vestido, que chega a pé pra dar aula ... não pode representar pro camarada uma possibilidade de ascensão social.

Embora nesse seu fragmento de pensamento acima Eli coloque sua visão de professor na opinião de um aluno hipotético, essa pode ser perfeitamente sua auto-imagem como professor. Sua trajetória para lidar com o conflito de afirmação de seu papel como professor parte daquela idéia de um professor poderoso e com prestígio social e caminha por uma mudança, em que ele diz ter percebido a necessidade se enxergar as dificuldades do aluno, mas desemboca em uma visão angustiada onde ele revela frustração com a profissão. Mesmo sendo um professor novato, Eli não se aproximou dos alunos numa perspectiva afetiva, como previa o modelo de desenvolvimento de conflitos para o conflito de papel.

Do ponto de vista cognitivo, por trás de uma visão angustiada da profissão, desenvolveu um estilo de ensino centrado no professor, no sentido que discutem Simmons et al. [15]. Quando esse estilo começou a dar sinais de exaustão, culpou os alunos, a escola, a política, a sociedade, mas não cogitou em nenhum momento rever 
seu papel de um professor tradicional.

Não fazendo ajustes de longo prazo no seu sistema de crenças quanto ao papel de professor, defendendo o núcleo duro de suas crenças, Eli enfrenta seu conflito de papel, no fundamental usando estratégias do nível I e, por vezes, II.

Eli continua a dar aulas da forma que julga natural. Os alunos continuam a reclamar de que não estão entendendo, mas sua análise sobre isso vai sempre na direção de atribuição de culpa principalmente aos próprios alunos. No mesmo mês de novembro de 1998, ao comentar em seu diário de estágio sobre uma de suas aulas, ele continuava enfrentando problemas com os alunos, contudo continuava também a não perceber as limitações de sua forma de ver o ensino de física.

Nessa aula fizemos uma breve revisão e passamos à execução de exercícios, lendo e interpretando os enunciados, pois esta função é tão deficitária quanto as operações básicas. A aula foi boa? Creio que sim, embora muitas vezes eu ache que não consegui que a maioria se interessasse. Eu posso encontrar diversas desculpas ou razões para que tantos se sintam pouco à vontade com a matéria, mas como ter realmente uma aula produtiva quando muitos não sabem a tabuada. Falar com os professores de matemática em nada resolve, porque eles já desistiram e continuam a matéria normalmente, como se nada pudesse ser feito. Como posso gerar satisfação em quem raramente logra êxito nos exercícios?

Em nossa segunda entrevista, incomodado com a manutenção de sua argumentação na qual, ao analisar seus problemas, ele sempre atribuía culpa a fatores externos, quase nunca se colocando como parte do problema, nos perguntamos justamente essa sua posição de se auto-excluir da situação.

(...) Agora, quanto ao fato de eu botar culpa sempre do lado de fora é porque, aqui do meu lado, eu tento fazer o que eu acho que é o melhor. Nesse momento, eu estou fazendo assim, porque eu não consigo ver um jeito melhor. Estou procurando fazer o melhor de tudo. Então, a partir do momento que você faz o melhor, e não tá dando certo, então você vai ver daqui para fora. Amanhã se eu enxergar um defeito aqui, eu me conserto, mudo. Então sempre estou tentando fazer desse lado aqui o melhor possível. É por isso que estou procurando defeitos lá fora. O defeito aqui dentro eu procuro todo dia. Se eu gritei numa classe e achei que meu desempenho foi uma porcaria, amanhã eu não grito mais. Se eu não gritei e achei que se gritasse seria melhor, amanhã eu experimento. Todo lado de cá, eu estou tentando todo o dia.

Realmente Eli percebe que há um conflito na condução de suas aulas e que no fundo revelam a sua própria visão de ensino. Mas não sabe dar aulas de outra forma. Quando se discute na Universidade outras visões sobre como ensinar e ele não tentar a inovação proposta, obviamente é porque no fundo não acredita nessas inovações. Faz ajustes mínimos em sua prática, adotando estratégias para lidar com o conflito que se configura como sendo do tipo II. Assume que tem conflito, propondo pequenas mudanças instrucionais e mantendo íntegro o núcleo duro de seu sistema de crenças [2].

Do ponto de vista de seus conflitos institucionais ou contextuais, também da mesma forma como os outros conflitos, não percebemos nenhuma modificação substancial em relação às crenças de Eli quanto à pressão para se adaptar ao sistema escolar ao qual se refere o modelo de conflitos, permanecendo a análise que fizemos quando de nossa primeira entrevista.

Quanto aos seus conflitos instrucionais em relação às suas percepções da expectativa da licenciatura em física, em meados de novembro de 1998, a discussão dentro da disciplina de Prática de Ensino de Física II se voltava exatamente para a crítica a essa visão de que o ensino de física tinha que ser dessa maneira que Eli trabalhava: treinamento de resolução de exercícios.

A discussão apontava para as vantagens da utilização de problemas abertos como uma forma de mudança necessária para o ensino de física. Em seu diário de estágio, Eli registra suas impressões sobre a inovação.

Esta postura de solução de problemas, que enfoca a teoria $e$ as hipóteses, não é fácil de se produzir, até mesmo porque o próprio professor está impregnado pelo mecanismo proporcionado pelo tipo de questões que ele se habituou a resolver, e por vezes se habituou a ensinar. É difícil romper com costumes tão fixados e que dão muita segurança ao professor, sem esquecer que propiciam uma falsa, mas agradável, sensação de aprendizagem ao aluno.

As palavras de Eli sobre a inovação que estava sendo discutida na Universidade são auto-explicativas. Ele julga que aprendeu física treinando resolução de exercícios, e é assim que seus alunos terão que aprender. Solução de problemas abertos não cabem em sua prática. Ele não sabe como fazer. Mas o que chamava mais atenção em seu pensamento acima era o fato dele falar que tinha segurança trabalhando do jeito que trabalhava, mesmo sabendo de antemão que havia "uma falsa, mas agradável, sensação de aprendizagem ao aluno" indo contra o espírito da inovação sugerida pela disciplina na Universidade. Havia, sem dúvida, uma evidente contradição em seu pensamento.

\section{Considerações finais}

Todos os quatro conflitos da tipologia proposta por Beach \& Pearson [2], Eli viu emergir em seu desenvolvimento desde o primeiro dia de seu trabalho na escola. A forma como lidou com cada um desses conflitos foi semelhante: protegeu seu sistema de crenças não aceitando as contribuições vindas do programa de formação.

Pensando o desenvolvimento de Eli em termos dos modelos de preocupações em fases, ele viveu em seu primeiro ano de trabalho exclusivamente a fase de preocupações consigo mesmo, caracterizada por um discurso em que publicamente se dizia preocupado com o desenvolvimento dos estudantes, mas a preocupação com sua performance $\mathrm{o}$ absorvia de tal maneira que não conseguiu ter $\mathrm{o}$ foco dirigido para o desenvolvimento de seus alunos.

Desenvolveu uma preocupação central com o comportamento de seus alunos em sala de aula, e com o comportamento de pouco caso acadêmico que enxergava em seus alunos. Seus conflitos não lhe servem como pontos de apoio para refletir sobre sua prática, de maneira a saber lidar com eles quando voltarem a ocorrer. Tem grandes dificuldades em construir relações de trabalho com o staff escolar. Contempla integralmente as características de um professor novato que viveu durante seu primeiro ano como professor exclusivamente a fase de preocupações consigo mesmo [1],[6],[7],[14],[15].

A relação de Eli com o programa de formação, talvez seja 
um aspecto relevante de seu desenvolvimento profissional para a pesquisa sobre formação de professores. Ou seja, a questão é saber como o formador de professor pode ajudar casos como o de Eli que tinha toda essa gama de dificuldades que tentamos descrever e analisar durante o artigo. Uma conclusão direta sobre o caso Eli seria a de que os programas de formação e os formadores de professores deveriam considerar como extremamente relevantes as preocupações e os conflitos que surgem na prática do professor novato. Temos que pensar formas de compatibilizar os objetivos da formação inicial com as necessidades dos professores ou com os problemas da prática que surgem quando o professor se inicia na profissão. Algumas questões são levantadas ao final do estudo desse caso: Há uma maneira de ajudar professores novatos que apresentam um perfil de desenvolvimento semelhante ao de Eli? Dentro dos programas de formação abrir espaços para discussão de conflitos, preocupações e problemas derivados da prática, podem ajudar o professor novato? Seria uma alternativa interessante o estudo de casos como o de Eli, ou de outros casos diferentes, dentro das disciplinas do programa de formação?

Novas pesquisas precisam ser feitas nessa direção para verificar se de fato essas nossas considerações fazem eco dentro de nossas licenciaturas em ciências.

\section{Referências}

[1] P.E. Adams and G.H. Krockover, Science Education 81, 29 (1997).

[2] R. Beach and D. Pearson, Teaching \& Teacher Education 14, 337 (1998)

[3] N.R.R. Bejarano, Tornando-se Professor de Física: Conflitos e Preocupações na Formação Inicial. Tese de Doutoramento, FEUSP, 2001.
[4] D. Silva, O Ensino Construtivista da Velocidade Angular (Textos - pesquisa para o ensino de Ciências, n. 3).

[5] Faculdade de Educação da Universidade de São Paulo, São Paulo (1990).

[6] F.F. Fuller, American Educational Research Journal 2, 207 (1969).

[7] F.F. Fuller and O.H. Bown, Becoming a Teacher, edited by K. Ryan Teacher Education. ( $74^{\text {th }}$ Yearbook of the National Society for the Study of Education, University of Chicago Press, Chicago, 1975).

[8] Dona M. Kagan, Review of Educational Research 62, 129 (1992).

[9] A.T. Lumpe, J.J. Haney, C.M. Czerniak, Journal of Research in Science Teaching 37, 275 (2000).

[10] V. Mellado, Science Education 82, 197 (1998).

[11] E.B. Nettle, Teaching \& Teacher Education 14, 193 (1998).

[12] F.M. Pajares, Review of Educational Research 62, 307 (1992).

[13] D.N. Paraná, Física para o Ensino Médio (Editora Ática, São Paulo, 1999).

[14] F.L. Pigge and R.N. Marso, Teaching \& Teacher Education 13, 225 (1997).

[15] P.E. Simmons, et al. Journal of Research in Science Teaching 36, 930 (1999).

[16] L.S. Shulman, Educational Researcher 15, 4 (1986).

[17] A. Villani, Rev. Bras. Ens. de Fis. 6, 76 (1996).

[18] Para maiores detalhes sobre "o caso Ani" ver em Bejarano \& Carvalho (2003), revista Ciência \& Educação, v. 9. n. 1 